\title{
Observation of the embryonic development in Pseudoplatystoma coruscans (Siluriformes: Pimelodidae) under light and scanning electron microscopy
}

\author{
Camila Marques $^{1,2,3}$, Laura Satiko Okada Nakaghi $i^{2,3}$, Francine Faustino ${ }^{2}$, Luciana Nakaghi Ganeco ${ }^{2}$ \\ and José Augusto Senhorini ${ }^{4}$ \\ Aquaculture Center of UNESP, CAUNESP and Departamento de Morfologia e Fisiologia Animal, UNESP - São Paulo State \\ University, Jaboticabal; and Centro de Pesquisa e Gestão de Recursos Pesqueiros Continentais - CEPTA/IBAMA, \\ Pirassununga, SP, Brazil
}

Date submitted: 10.10.07. Date accepted: 20.02 .08

\section{Summary}

Pseudoplatystoma coruscans is a very popular species for tropical fish culture as it has boneless meat of delicate taste and firm texture. Few studies on fish reproductive biology refer to the morphological features of eggs. The goal, therefore, of this present work was to perform a structural and ultrastructural analysis of fertilization and embryonic development in P. coruscans. The incubation period, from fertilization to hatching, lasts $13 \mathrm{~h}$ at $28 / 29^{\circ} \mathrm{C}$ and $18 \mathrm{~h}$ at $27^{\circ} \mathrm{C}$. The oocytes had a mean diameter of $0.95 \mathrm{~mm}$ and hatched larvae were $2.55 \mathrm{~mm}$ in diameter. Analysing their development, we observed round, yellow oocytes that bore a double chorion membrane and a single micropyle. At $10 \mathrm{~s}$ after fertilization, several spermatozoa were detected attached to the oocyte surface. After $1 \mathrm{~min}$ of development, a fertilization cone that obstructed the micropyle could be observed. Segmentation started between 20 and $30 \mathrm{~min}$ after fertilization, when the egg cell was then formed. The first cleavage occurred between 30 and $45 \mathrm{~min}$ after fertilization, prior to reaching the morula stage (75 and $90 \mathrm{~min}$ after fertilization). The epiboly movement started at 120 and 180 min after fertilization and ended at 360 and 480 min after fertilization. Differentiation between cephalic and caudal region was detected after 420 and 600 min after fertilization and larvae hatched between 780 and $1080 \mathrm{~min}$ after fertilization. Seven main embryonic development stages were identified: egg cell, cleavage, morula, blastula, gastrula, segmentation with differentiation between cephalic and caudal regions, and hatching.

Keywords: Eggs, Embryology, Morphology, Pseudoplatystoma coruscans, SEM

\footnotetext{
${ }^{1}$ All correspondence to: C. Marques. Departamento de Morfologia e Fisiologia Animal, UNESP - São Paulo State University, Via de Acesso Prof. Paulo Donato Castellane, s/n, CEP 14884-900, Jaboticabal, SP, Brazil. Tel:/Fax: +55 16 3209-2654 (r. 232). e-mail: marques.cami@yahoo.com.br

${ }^{2}$ Aquaculture Center of UNESP, CAUNESP, Via de Acesso Prof. Paulo Donato Castellane, s/n, CEP 14884-900, Jaboticabal, SP, Brazil.

${ }^{3}$ Departamento de Morfologia e Fisiologia Animal, UNESP São Paulo State University, Via de Acesso Prof. Paulo Donato Castellane, s/n, CEP 14884-900, Jaboticabal, SP, Brazil.

${ }^{4}$ Centro de Pesquisa e Gestão de Recursos Pesqueiros Continentais - CEPTA/IBAMA, Rod. SP 201, Km 6.5, P.O. Box 64, CEP 13630-970, Pirassununga, SP, Brazil.
}

\section{Introduction}

The fish Pseudoplatystoma coruscans is a large example of the species, characterized by a dark-spotted body, and is popularly known as spotted sorubim. This fish is found in the Amazon, São Francisco and Pratta river basins (Nakatani et al., 2001) and is a very popular fish in Brazilian culture because of its high quality meat (Kubitza et al., 1998).

P. coruscans exhibits full spawning, external fertilization and parental care (Vazzoler, 1996). As this species undergoes reproductive migration, changes in the exogenous features, which trigger both gonadal development and reproduction directly, affect survival rates and, along with overfishing, these changes seem to be the major cause of population breakdown in 
P. coruscans in rivers in the state of São Paulo, Brazil (Vazzoler, 1996).

Despite technological advances in artificial reproduction and incubation, some basic aspects that are related to the embryonic stages in these fish, from fertilization to hatching, are still poorly evaluated (Shardo, 1995). The study of the initial life cycle phases is essential for elucidating both taxonomic and ecological issues (Sanches et al., 1999).

Embryonic development is a complex process that needs an understanding of fish ontogeny. This understanding is also useful for biotechnological experiments or as environmental bioindicators and to evaluate the effects of toxic substances on aquatic fauna. Thus, embryos can be used in multifunctional approaches (Flores et al., 2002; Botero et al., 2004; Ninhaus-Silveira et al., 2006). Information on the embryonic development of $P$. coruscans is scarce and is restricted to reports by Cardoso et al. (1995) and Landines et al. (2003). The goal of the present work, therefore, was to perform a structural and ultrastructural analysis of the morphological events during fertilization and embryonic development in P. coruscans.

\section{Materials and methods}

Three oocyte and egg collections were carried out at the Centro de Pesquisa e Gestão de Recursos Pesqueiros Continentais - CEPTA/IBAMA, in Pirassununga - SP, during the reproductive season. The first collection was performed in January, while the other collections were performed in December 2004. The induced reproduction of $P$. coruscans and dry fertilization were carried out according to the method described by Woynarovich \& Hórvath (1983). Adults were induced using carp hypophysis extract (CHE). Two doses $(0.5 \mathrm{mg} / \mathrm{kg}$ and $5.0 \mathrm{mg} / \mathrm{kg}$, respectively) were applied to females at $10 \mathrm{~h}$ intervals. A single $1 \mathrm{mg} / \mathrm{kg}$ injection was applied to males, as the same time as the second female injection.

Specimens of $P$. coruscans were collected during oocyte extrusion, just when oocytes and sperm were mixed (fertilization $=$ time 0 ), at 10 and $30 \mathrm{~s}$ after fertilization, 1, 2, 5, 7, 10, 15, 20, 30 and $45 \mathrm{~min}$ after fertilization and at each 15 min up to $2 \mathrm{~h}$ after fertilization as well as each hour until hatching.

After extrusion, oocytes were kept in a bowl and sperm were added and gently homogenized. Egg hydration was performed $1 \mathrm{~min}$ after fertilization. The eggs were transferred to 601 incubators at an estimated rate of 1000 eggs/1 (60 000 eggs/incubator). The water flow during the first $5 \mathrm{~h}$ of development was $5 \mathrm{l} / \mathrm{min}$ and, from final incubation to hatching, flow was increased to $10 \mathrm{l} / \mathrm{min}$. Fertilization rate was calculated $5 \mathrm{~h}$ after mixing male and female gametes (fertilization time).

Sample processing and analysis was performed in the Histology and Embryology Laboratory at the Morphology and Animal Physiology Department and Electronic Microscopy Laboratory, FCAV-UNESP, Jaboticabal campus.

Samples were fixed in Karnovsky's fixative solution (2.5\% glutaraldehyde $+2.5 \%$ paraformaldehyde) for $24 \mathrm{~h}$, rinsed in $0.1 \mathrm{M}$ sodium cacodylate buffer ( $\mathrm{pH} 7.4$ ) and stored in $70 \%$ alcohol for further analysis according to the following methodologies:

\section{Stereomicroscopic analysis and morphometry}

The oocyte/egg diameter at each sampling period was measured using a ZEISS stereomicroscope with a micrometer (optical lens scale $=1 \mathrm{~mm}$ ). Then, the oocytes and eggs were selected and photomicrographed in a LEICA stereomicroscope.

\section{Light microscopy (LM)}

Samples of oocytes and eggs that had been selected for light microscopy analysis were embedded in paraffin and historesin and cut into 3 to $5 \mu \mathrm{m}$ diameter slices, mounted in slides, stained with haematoxylin-eosin (HE) (Tolosa et al., 2003) and photomicrographed in an AXIOSKOP-ZEISS photomicroscope.

\section{Scanning electron microscopy}

After washing in sodium cacodylate buffer, the samples were post-fixed in $1 \%$ osmium tetroxide for $2 \mathrm{~h}$, washed again, dehydrated in ethanol series, critical point dried in liquid $\mathrm{CO}_{2}$ drier (BALTEC), mounted in copper grid, metalized in gold-palladium and observed in a scanning electron microscopy (SEM) (JEOL-JSM 5410).

\section{Results}

The embryonic period of Pseudoplatystoma coruscans, from fertilization to hatching, lasted $18 \mathrm{~h}$ at $27^{\circ} \mathrm{C}$ in the first collection, $13 \mathrm{~h}$ at $28^{\circ} \mathrm{C}$ in the second one and $13 \mathrm{~h}$ at $29^{\circ} \mathrm{C}$ in the latter.

Fertilization rate was considered high in the first collection ( $88 \%$ average). In the other collections, the fertilization rates were low (a mean value of 13\%).

During extrusion, the oocytes sampled in the three collections, had a mean diameter of $0.95 \mathrm{~mm}$, which increased prior to larval hatching, then reaching a mean diameter of $2.55 \mathrm{~mm}$.

Table 1 shows the main egg development stages and their features, with times for the three collections. It is noteworthy that development times were 
Table 1 Description of development stages in P. coruscans eggs observed in stereomicroscopes at each collection moment.

\begin{tabular}{|c|c|c|c|c|}
\hline \multirow[b]{2}{*}{ Stages } & \multicolumn{3}{|c|}{ Post-fertilization time (min) } & \multirow[b]{2}{*}{ Description } \\
\hline & Collection 1 & Collection 2 & Collection 3 & \\
\hline Egg cell or blastodisc & 30 & 20 & 20 & Animal pole (PA) will initiate segmentation \\
\hline Cleavage & 45 & 30 & 30 & $\begin{array}{l}\text { 1st cleavage }-2 \text { blastomeres; } 2 \text { nd cleavage }-4 \\
\text { blastomeres }\end{array}$ \\
\hline Cleavage & 60 & 45 & 45 & $\begin{array}{l}\text { 3rd cleavage }-8 \text { blastomeres; } 4 \text { th cleavage }- \\
16 \text { blastomeres }\end{array}$ \\
\hline Morula & 90 & 75 & 75 & AP bears more than 64 blastomeres \\
\hline Blastula & 180 & 120 & 120 & Cell boundaries are not defined \\
\hline Gastrula & 300 & 180 & 180 & Epiboly \\
\hline Gastrula-yolk plug & 480 & 360 & 360 & $\begin{array}{l}\text { Yolk not covered by embryonic cells, end of } \\
\text { gastrula stage }\end{array}$ \\
\hline Segmentation & 600 & 420 & 420 & $\begin{array}{l}\text { Presence of vesicles (optical and Kuppfer's) } \\
\text { and somites. Development of caudal and } \\
\text { cephalic regions }\end{array}$ \\
\hline Hatching & 1080 & 780 & 780 & Total chorion rupture \\
\hline
\end{tabular}

not coincident in the collections, as they were not synchronic.

\section{Stereomicroscope analysis}

P. coruscans had round yellowish eggs that bore a double chorion membrane with a gelatinous layer over the chorion, which provided $\backslash$ some adherence to eggs (Fig. 1a).

The phases mentioned in Table 1 are represented in Fig. $1(b-k)$. The egg cell was identified at $30 \mathrm{~min}$ after fertilization in the first collection and $20 \mathrm{~min}$ after fertilization in the second and third collections. This phase is the beginning of segmentation, also referred to as blastodisc. Cleavage follows, when the blastodisc divides into 2, 4, 8, 16, 32 and 64 blastomeres, this stage started 45 min after fertilization in the first collection and $30 \mathrm{~min}$ after fertilization in the second and third collections.

The presence of more than 64 blastomeres, characterstic of the morula stage, was observed $90 \mathrm{~min}$ after fertilization in the first collection; while, in the other collections, this stage was detected after $75 \mathrm{~min}$. The blastula stage, when cell boundaries could no longer be defined, was observed after $120 \mathrm{~min}$ in the two latter collections and after $180 \mathrm{~min}$ after fertilization in the first collection.

The gastrula stage, characterized by epiboly movement, started $300 \mathrm{~min}$ after fertilization in the first collection and after $180 \mathrm{~min}$ in the others. At $360 \mathrm{~min}$ after fertilization in the second and third collections and at $480 \mathrm{~min}$ after fertilization in the first collection, the yolk was nearly all covered by embryonic cells, forming the yolk plug, characterizing the end of the gastrula stage.
After $600 \mathrm{~min}$, the cephalic embryo region could be differentiated from the caudal region in the first collection. This stage was observed after $420 \mathrm{~min}$ in the second and third collections. The somites and the optical vesicle were detected $660 \mathrm{~min}$ after fertilization in the first collection and after 480 and 540 min in the second and third collections, respectively (Fig. 1j).

After $720 \mathrm{~min}$ in the first collection and at $540 \mathrm{~min}$ after fertilization in the others, the tail became more elongated. Hatching began after $1020 \mathrm{~min}$ of development and lasted up to full chorion rupture at $1080 \mathrm{~min}$ after fertilization (Fig. $1 \mathrm{k}$ ) in the first collection and after $720 \mathrm{~min}$ in the second and third collections.

In the present study, P. coruscans larvae were shown to have an elongated and transparent body, free of pigmentation.

\section{Scanning electron microscopy and light microscopy analysis}

The presence of a micropyle, i.e. a small and specialized opening for sperm penetration during fertilization, was revealed by SEM analysis (Fig. 2a). The micropylar apparatus of $P$. coruscans, comprising the vestibule and the micropylar canal, was characterized by a conical vestibule, smooth surface, without any special features and a narrow micropylar canal. The micropylar canal was surrounded by a thick margin.

Under light microscopy (LM), it was possible to observe movement of the cytoplasm (arrow) towards the micropyle region in the oocytes collected at the moment of fertilization, characterizing the animal pole 

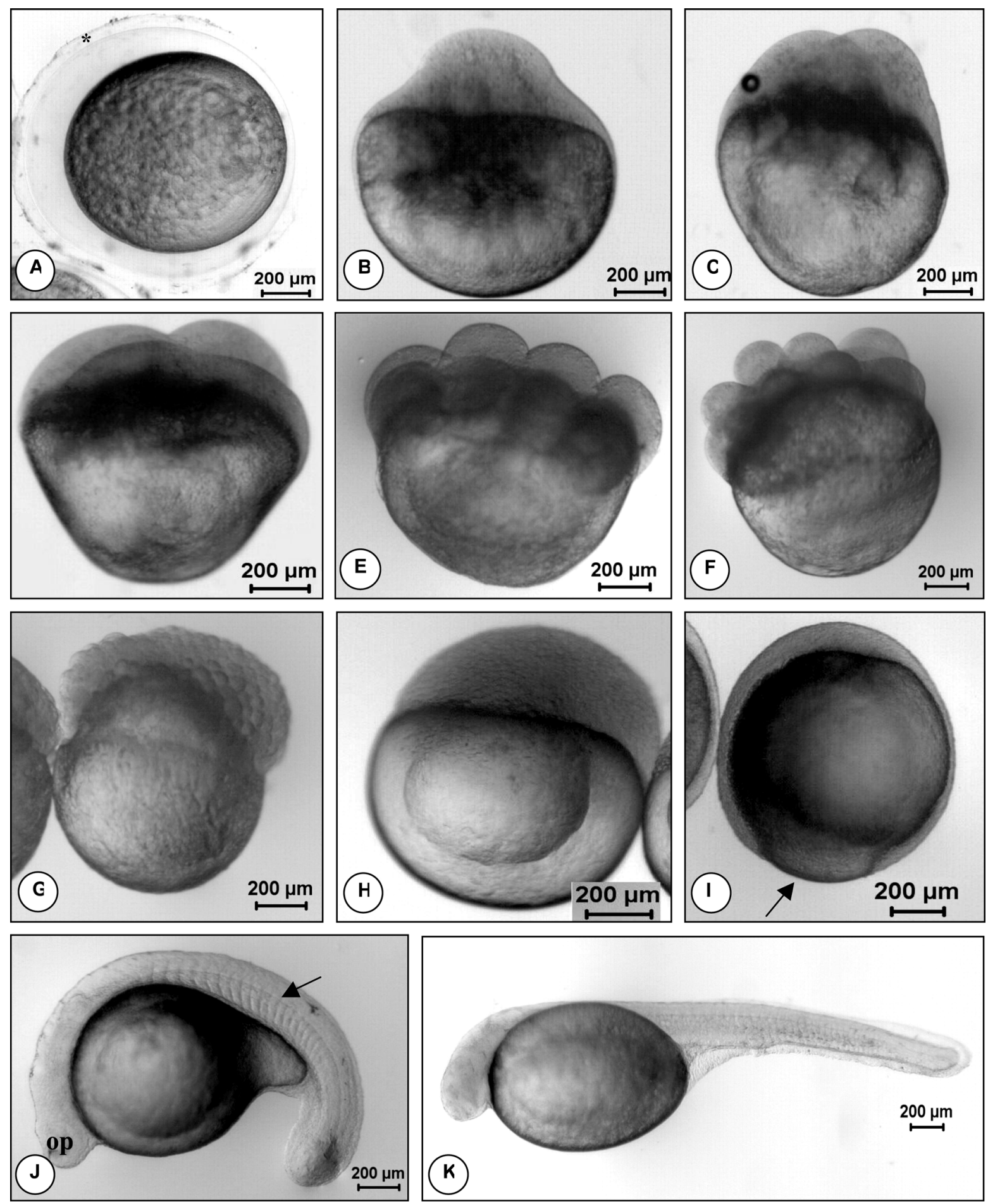

Figure 1 (a) Photomicrographs of P. coruscans oocytes - presence of a double chorion membrane $(*) ;(b-i)$ egg of $P$. coruscans; (b) egg cell or blastodisc; (c) presence of 2 blastomeres; $(d) 4$ blastomeres; (e) 8 blastomeres, $(f) 16$ blastomeres; $(g)$ morula stage; (h) blastula stage; (i) gastrula stage, formation of yolk plug (arrow); $(j, k)$ embryo; $(j)$ differentiation of cephalic and caudal region, presence of somites (arrow) and optical vesicle (op); $(k)$ newly hatched larva.

(ap) (Fig. 3a). At time 0 (mixing of sperm and oocytes), the initial formation of animal and vegetative poles was detected. The vegetative pole was composed of the yolk and the animal pole was formed by the fusion between masculine and feminine pronuclei plus the displaced cytoplasm. The animal pole was basophilic 

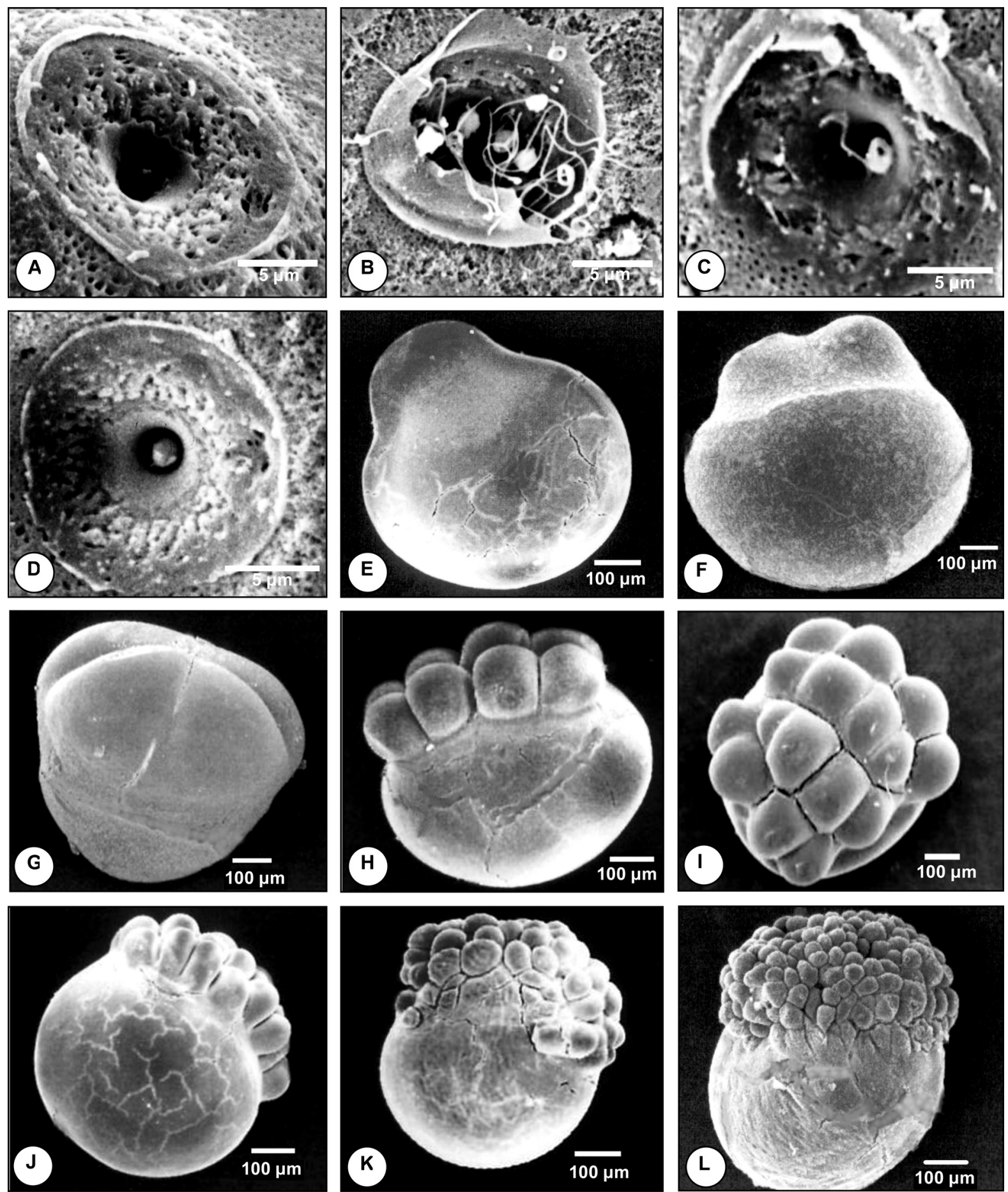

Figure 2 Scanning electron micrographs of the oocyte/egg of P. coruscans. (a) micropyle region in the oocyte at the extrusion; (b) presence of several spermatozoa at the entrance of oocyte micropylar region; (c) visualization of a spermatozoon at the micropyle entrance; $(d)$ egg during the formation of fertilization cone (arrow); $(e)$ formation of egg cell, when the animal pole is about to begin the segmentation; $(f-k)$ presence of $2,4,8,16,32$ and 64 blastomeres, respectively; $(l)$ morula stage.

and homogeneous. The vegetative pole was acidophilic and presented yolk grains, which became smaller and scarcer when located close to the animal pole (Fig. 3b). The largest and more abundant granules, located in the cytoplasm opposite to animal pole, were derived from the coalescence of yolk grains (Fig. 3c).

Several cortical alveoli, aligned through the entire oocyte margin, were observed in the cortical cytoplasm 

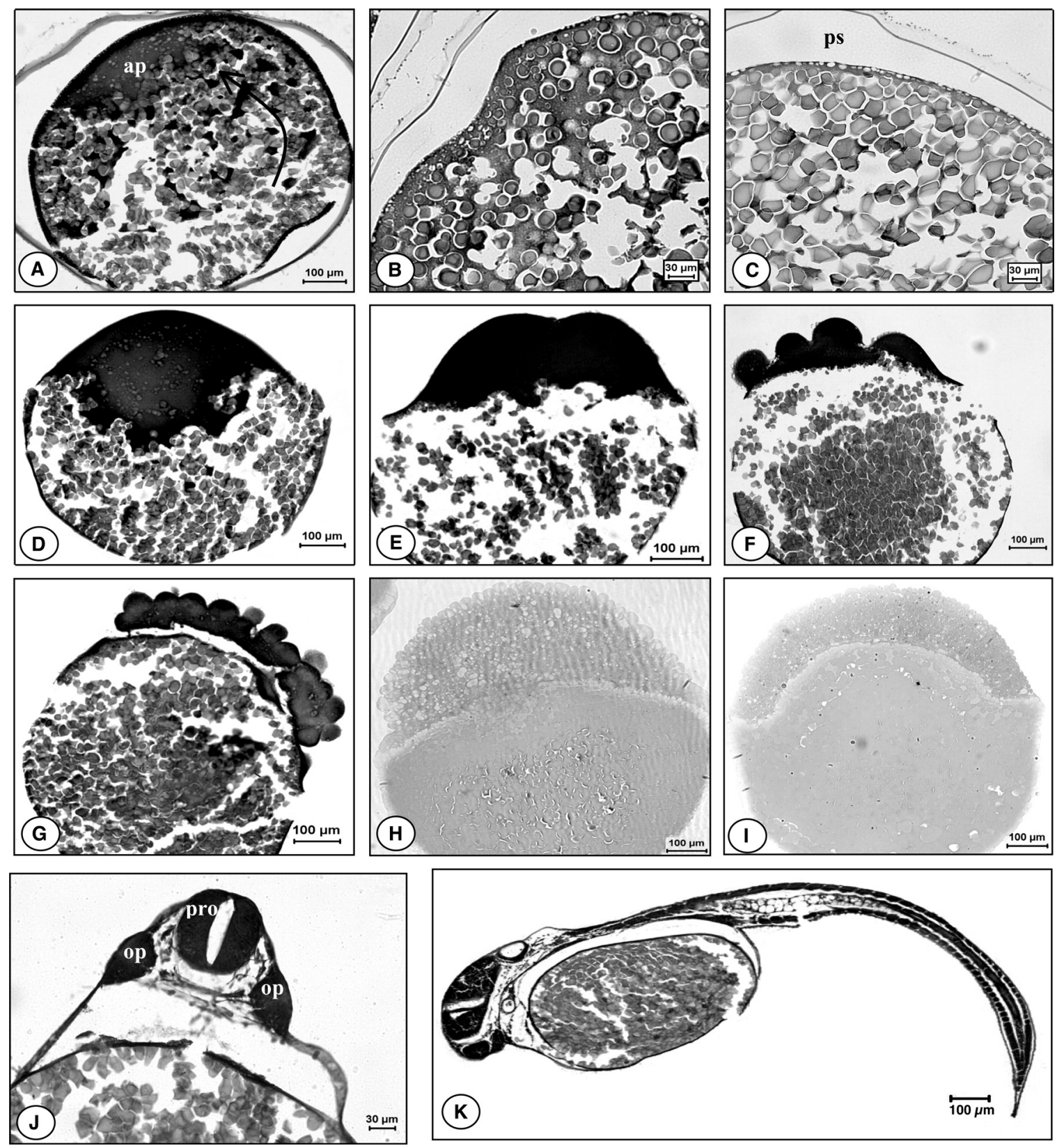

Figure 3 Photomicrographs of the eggs/embryo of P. coruscans. (a) during the fertilization, where the cytoplasmatic movement (arrow) can be observed towards the animal pole (ap); (b) a few cortical alveoli and small yolk grains in the animal pole; (c) a high number of cortical alveoli and enlarging of yolk grains in the vegetative pole; ps: perivitelline space; $(d)$ formation of egg-cell; $(e, f)$ presence of 2 and 8 blastomeres, respectively; $(g)$ morula stage; $(h)$ blastula stage; $(i)$ gastrula stage; $(j)$ visualization of prosencephalon (pro) and optical vesicle (op); (k) newly hatched larva (HE).

during fertilization, composing a thin basophilic layer. The number of cortical alveoli layers present in the oocyte margin had decreased after the fertilization of P. coruscans oocytes.

The rupture of cortical alveoli triggered chorion elevation and the consequent enlargement of the perivitelline space, leading to a significant increase in the egg diameter, from $7 \mathrm{~min}$ after fertilization on, due to egg hydration. After $10 \mathrm{~min}$ after fertilization, cortical alveoli were absent.
The formation of perivitelline space in the spotted sorubim (Fig. $3 c$ ) and its enlargement resulted in the separation of chorion and egg membrane.

Several spermatozoa were observed at the micropyle entrance and a single spermatozoon was detected moving towards the micropyle canal after ' $10 \mathrm{~s}$ ', in SEM analysis, indicating a probable fertilization (Fig. 2b, $c$ respectively). Sperm penetration promoted fertilization, as confirmed by the formation of a cone $30 \mathrm{~s}$ after fertilization (Fig. $2 d$ ), a spherical structure that 

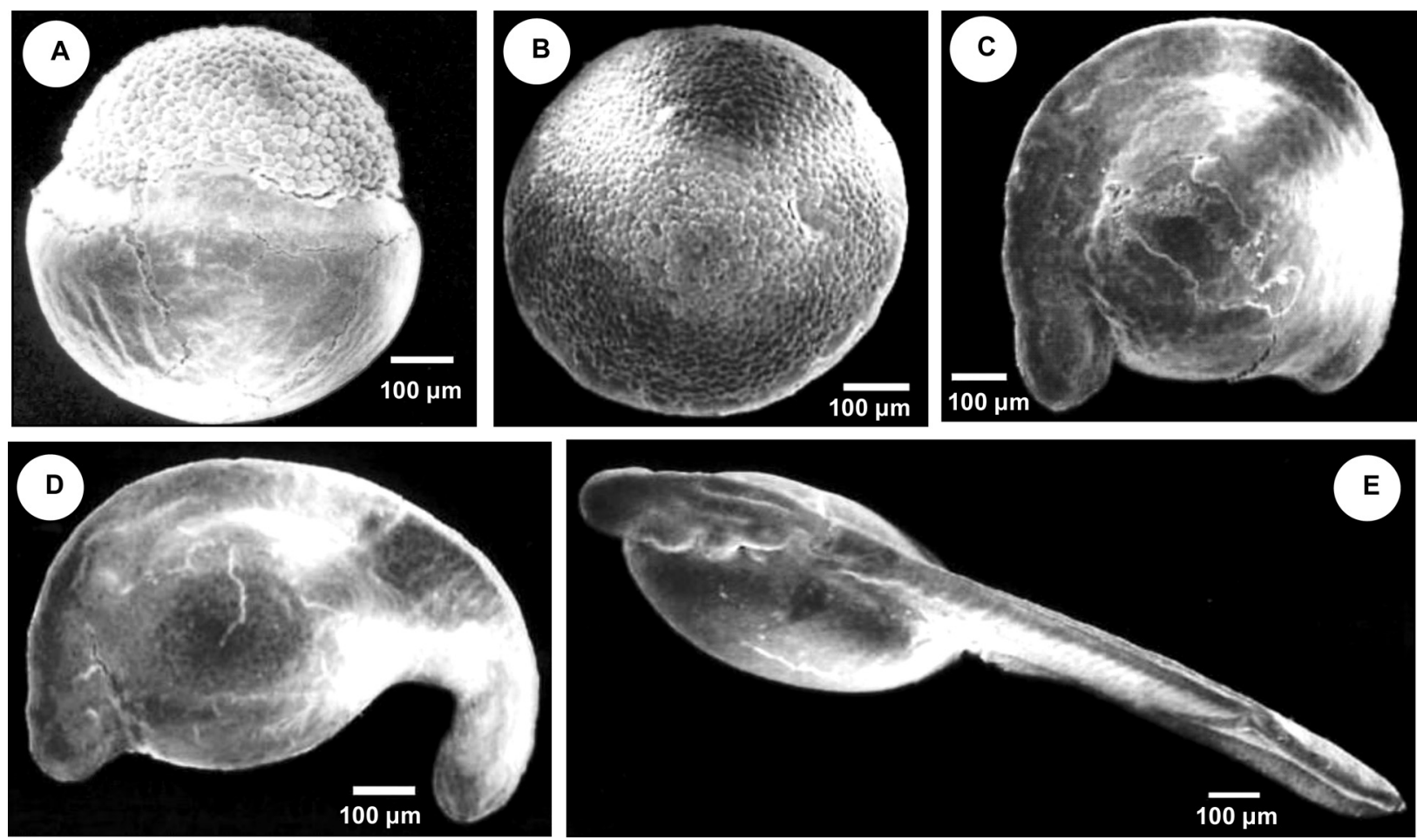

Figure 4 Scanning electron micrograph of the P. coruscans egg/embryo. (a) blastula stage; $(b)$ gastrula stage; (c) differentiation of cephalic and caudal region; $(d)$ embryo elongation through cephalic-caudal axis; $(e)$ newly hatched larva, rise of the primordial barbells $\left({ }^{*}\right)$.

trespassed the micropyle, and obstructed its opening. Such fertilization cone would act as a mechanism to prevent polyspermy.

After the fertilization-related events, the egg had undergone several modifications, comprising cleavages, cell movement and the formation of organ outlines. The blastodisc or egg cell was formed prior to the first cleavage (Figs. 2e, 3d).

The first cleavage divided the blastodisc into 2 cells (blastomeres) of the same size (Figs. 2f, 3e). Then, these 2 cells divided, giving rise to 4 blastomeres (Fig. $2 g$ ) and so on, i.e., each cell divided, producing $8,16,32$ and 64 blastomeres (Figs. $2 h, 3 f ; 2 i ; 2 j ; 2 k ; 3 g$ respectively). With time, the number of blastomeres increased and their size diminished.

After a 64 blastomere stage was reached, the morula stage was initiated (Fig. 2l), when the blastomeres formed a mulberry-like cell mass. The blastula stage followed, characterized by the blastoderm origin, and the size and disposition of blastomeres (Figs. 3h; 4a).

After the blastula stage, the embryonic cells migrated, giving rise to a fringe that projected downwards and opposite to the blastoderm epiboly movement, forming, therefore, the epiblast and the hypoblast, characteristic of the gastrula stage (Figs. 3i, $4 b)$. This phase was completed with the closure of the blastopore by the blastoderm and by the formation of a tail button.
The formation of cephalic and caudal regions, somites and optical vesicle was observed by SEM, (Fig. 4c) and the embryo became larger and more elongated in the cephalic-caudal axis (Fig. $4 d$ ). Some primordial barbells could also be seen by SEM (Fig. 4e).

The anterior region of the neural tube in the spotted sorubim was expanded, giving rise to prosencephalon (Fig. 3J), mesencephalon and rhombencephalon regions. The detection of a free tail and consequent rupture of chorion, characterizing the larval hatching, are shown in the Figs. $3 k, 4 e$.

\section{Discussion}

Fish eggs are classified as telolecithal, as they present a great amount of yolk widely distributed (Ribeiro et al., 1995; Leme dos Santos \& Azoubel, 1996). The eggs of $P$. coruscans fit this classification and, thus, present meroblastic or partial cleavages, restricted to the animal pole. Such cleavage is typical of fish eggs (Lagler et al., 1977; Leme dos Santos \& Azoubel, 1996).

The mean diameter of oocytes in $P$. coruscans at the extrusion time was equal to $0.95 \mathrm{~mm}$ and, at hatching, the mean diameter was $2.55 \mathrm{~mm}$. Landines et al. (2003) observed a mean diameter of $2.69 \mathrm{~mm}$ for newly hatched larvae in the same species, while 
Faustino et al. (2007) reported a mean diameter of $1.14 \mathrm{~mm}$ for oocytes and $3.28 \mathrm{~mm}$ for larvae in the sorubim hybrid $(P$. coruscans $\times P$. fasciatum). Oocyte diameter is likely to be related to the fertilization mode of each species; animals presenting external fertilization usually produce oocytes of a small diameter (Sanches et al., 1999), whereas those that use internal fertilization often present larger oocytes. For instance, Parauchenipterus galeatus is a species with internal fertilization, whose mean oocyte diameter reaches $1.62 \mathrm{~mm}$ (Vazzoler, 1996).

Moreover, Suzuki (1992) showed that some species, such as Hoplias malabaricus and Serrasalmus marginatus (piranha), which present parental care, produced oocytes that were more than $2.00 \mathrm{~mm}$ in diameter. The egg diameter also influences the incubation period, i.e., larger eggs have a longer incubation time (Sargent et al., 1987).

Such studies corroborate the present data, as, lacking parental care and presenting external fertilization, the $P$. coruscans produced eggs of a small diameter and presented a short incubation period.

Temperature is another feature that plays a role on incubation. At higher temperatures, the incubation time is shortened, while, at lower temperatures, this period is increased (Leme dos Santos \& Azoubel, 1996; Ninhaus-Silveira et al., 2006), as reported in the present study.

The presence of a double chorion membrane was also observed in the oocytes and eggs prior cleavages. The same structure was also reported by Cardoso et al. (1995) in P. coruscans and by Sanches et al. (1999) in P. galeatus.

The development times in each collection were distinct, as they were not simultaneous. Morrison et al. (2001) suggested that variations in the embryonic development rate and in the embryonic development (asynchrony and malformation) are related to the incubation period and breeder's age. Kimmel et al. (1995), Morrison et al. (2001) and Ninhaus-Silveira et al. (2006) showed that, even within a fertilized spawning incubated at optimal conditions, there is some asynchrony in the embryonic development time.

Analysing the micropylar apparatus in the oocytes, a conical vestibule, with a smooth surface and narrow micropylar canal, was observed. This micropylar canal is surrounded by a thick and gelatinous layer. According to Ganeco \& Nakaghi (2003), the micropyle is a concave region located in the radiate zone or chorion, composed of a continuum vestibule, with an internal canal that narrows towards to the plasmatic membrane of the egg.

Such micropyle shape allows the entry of a single spermatozoon, according to Kobayashi \& Yamamoto (1981) and Rizzo \& Bazzoli (1993). Other ways of preventing polyspermy include the formation of a fertilization cone, which obstructs the micropylar canal, as well as the releasing of cortical alveoli, which increases the perivitelline space after the fertilizing spermatozoon has entered (Ganeco, 2003).

At the moment of fertilization, cytoplasmatic movement towards the micropyle begins in the oocytes, which characterizes the animal pole. Similar observations were reported by Kimmel et al. (1995) and Leme dos Santos \& Azoubel (1996). Brasil et al. (2002) and Ganeco (2003), however, observed cytoplasmatic movement in eggs collected during the oocyte extrusion prior to fertilization. At the same time, the basophilic and homogeneous animal pole and the acidophilic vegetative pole were formed. Similar features were observed by Matkovic et al. (1985) in Rhamdia sapo.

The yolk grains were smaller and scarcer close to the vegetative pole and larger and more numerous close to the animal pole, as a result of the coalescence between yolk grains. Such a phenomenon was also observed in Prochilodus lineatus (Brasil et al., 2002) and Byrcon orbignyanus (Ganeco, 2003). The same relationship between number and size was also detected in the cortical alveoli: they were larger and more abundant in the vegetative pole and they became scarce and smaller in the animal pole. Few cortical alveoli at the animal pole region were also seen in Fundulus heteroclitus (Brummett \& Dumont, 1979) Oryzias latipes (Iwamatsu \& Ohta, 1981), Oncorhynchus keta (Kobayashi \& Yamamoto, 1981) and Prochilodus lineatus (Brasil et al., 2002). Ohta (1985) and Hart (1990) assumed that the small amount of cortical alveoli in the animal pole would be preventive, putting off the start of perivitelline space formation and favouring the entry of the fertilizing spermatozoon.

Laale (1980) observed a similar feature, pointing out that during exocytosis of cortical alveoli contents, $\mathrm{Ca}^{2+}$ ions are absorbed and they would be involved in chorion hardening, which would act as a mechanic protection for the developing embryo (Laale, 1980; Lönning et al., 1984).

Embryonic development encompassed all stages from fertilization to hatching, including cleavage, gastrulation and the beginning of organogenesis (Shardo, 1995).

The first cleavage divided the blastodisc into two blastomeres of the same size. A similar observation was reported in other species of the genus Cynolebias (Carter \& Wourms, 1991), in zebrafish (Kimmel et al., 1995) and in Prochilodus lineatus (Ninhaus-Silveira et al., 2006). Cleavage started from the centre towards the blastodisc margin (Matkovic et al., 1985; Shardo, 1995). Successive cleavage took place up to the 65 blastomere stage and as long as the number of blastomeres increased, their size decreased (Wourms \& Evans, 1974; Castellani et al., 1994; Ninhaus-Silveira et al., 2006). 
We observed that morula stage in the P. coruscans is followed by the blastula stage, which is characterized by the blastoderm formation and, then, by the gastrula stage, when epiboly movements begin (Leme dos Santos \& Azoubel, 1996), which extends up to the closure of the blastopore by the blastoderm and formation of the tail button (Kimmel et al., 1995). Similar observations were reported by Ninhaus-Silveira et al. (2006) in Prochilodus lineatus and by Ganeco (2003) in Byrcon orbignyanus.

The anterior region of the neural tube in the studied species expanded to form the prosencephalon, mesencephalon and rhombencephalon regions, similar to the patterns described in Brachydanio rerio (Kimmel et al., 1995), Rhamdia sapo (Cussac et al., 1985), Byrcon orbignyanus (Ganeco, (2003) and Prochilodus lineatus (Ninhaus-Silveira et al., 2006).

The present data, therefore, showed that the study of embryonic development is essential to a better knowledge of some biological features of a species, helpful to elucidate issues related to fish rearing at this stage, being also useful to further taxonomic, ecological and conservational studies in the P. coruscans.

\section{Acknowledgements}

The authors would like to thank CEPTA/IBAMA, especially Dr José Augusto Senhorini, for providing the samples and collection assistance; FAPESP, for the financial support (scientific initiation grant Proc. N 03/13112-0); and Mr Orandi Mateus for helping to process the material.

\section{References}

Botero, M., Fresneda, A., Montoya, A.F. \& Ángel, M.O. (2004). Descripción Del desarrollo embrionário de zigotos híbridos obtenidos por el cruce de machos de Cachama Blanca (Piaractus brachypomus) y hembras de Cachama Negra (Colossoma macropomum). Rev. Col. Cienc. Pec. 17, 38-45.

Brasil, D.F., Nakaghi, L.S.O., Leme dos Santos, H.S., Quagio Grassioto, I. \& Foresti, F. (2002). Estudo morfológico dos primeiros momentos da fertilização em curimbat Prochilodus lineatus (Valenciennes, 1836). [online], CIVA 2002. http://www.civa2002.org/, pp. 733-47.

Brummett, A.R. \& Dumont, J.N. (1979). Initial stages of sperm penetration into the egg of Fundulus heteroclitus. J. Exp. Zool. 201, 417-34.

Cardoso, E.L., Alves, M.S.D., Ferreira, R.M.A. \& Godinho, H.P. (1995). Embryogenesis of the neotropical freshwater Siluriformes Pseudoplatystoma coruscans. Aquat. Living Res. 8, 343-6.

Carter, C.A. \& Wourms, J.P. (1991). Cell behavior during early development in the South American annual fishes of the genus Cynolebias. J. Morphol. 210, 247-66.
Castellani, L.R., Tse, H.G., Leme dos Santos, H.S., Faria, R.H.S. \& Santos, M.L.S. (1994). Desenvolvimento embrionário do curimbatá Prochilodus lineatus (VALENCIENNES, 1836) (Cypriniformes, Prochidontidae). Rev. Bras. Cienc. Morf. 11, 99-105.

Cussac, V.E., Matkovic, M.V. \& Maggese, M.C. (1985). Desarrollo embrionário de Rhamdia sapo (Valenciennes, 1840) Eigenmann Y Eigenmann, 1888 (Pisces, Pimelodidae), I. Organogenesis media organogenesis tardia y eclosion. Rev. Bras. Biol. 45, 149-60.

Faustino, F., Nakaghi, L.S.O., Marques, C., Makino, L. \& Senhorini, J.A. (2007) Fertilização e desenvolvimento embrionário: morfometria e análise estereomicroscópica dos ovos dos híbridos de surubins (pintado, Pseudoplatystoma corruscans $\times$ cachara, Pseudoplatystoma fasciatum). Acta Sci. 29, 49-55.

Flores, J.C.B., Araiza, M.A.F. \& Valle, M.R.G. (2002). Desarrollo embrionário de Ctenopharyngodon idellus (Carpa herbívora). [online], CIVA 2002. http:/ / www.civa2002.org/, pp. 792-7.

Ganeco, L.N. (2003). Análise dos ovos de piracanjuba, Byrcon orbignyanus (Valenciennes, 1894), durante a fertilização e o desenvolvimento embrionário, sob condições de reprodução induzida. Masters degree, Universidade Estadual Paulista, Jaboticabal.

Ganeco, L.N. \& Nakaghi, L.S.O. (2003). Morfologia da micrópila e da superfície dos ovócitos de piracanjuba, Byrcon orbignyanus (Osteichthyes, Characidae), sob microscopia eletrônica de varredura. Acta Sci. 25, 227-31.

Hart, N.H. (1990). Fertilization in teleost fishes: mechanisms of sperm-egg interactions. Int. Rev. Cytol. 121, 1-66.

Iwamatsu, T. \& Ohta, T. (1981). Scanning electron microscopic observation on sperm penetration in teleostean fish. J. Exp. Zool. 218, 261-77.

Kimmel, C.B., Ballard, W.W., Kimmel, S.R \& Ullmann, B. (1995). Stages of embryonic development of the zebrafish. Dev. Dyn. 203, 253-310.

Kobayashi, W. \& Yamamoto, T. (1981). Fine structure of the micropylar apparatus of the chum salmon egg, with a discussion of the mechanism for blocking polyspermy. J. Exp. Zool. 217, 265-75.

Kubitza, F., Campos, J.L. \& Brum, J.A. (1998). Produção intensiva de surubins no projeto Pacu. Ltda. e Agropeixe Ltda. In Anais da Aquicultura, Recife, Pernambuco 1, 393407.

Laale, W.H. (1980). The perivitelline space and egg envelopes of bony fishes: a review. Copeia 2, 210-26.

Lagler, K.F., Bardach, J.E., Miller, R.R. \& Passino, D.R.M. (1977). Ichthyology, 2nd edn, New York: John Wiley \& Sons, Inc.

Landines, M.A., Senhorini, J.A., Sanabria, A.I. \& Urbinati, E.C. (2003). Desenvolvimento Embrionário do Pintado (Pseudoplatystoma coruscans Agassiz, 1829). Bol. Tec. Cepta 6, 1-13.

Leme dos Santos, H.S. \& Azoubel, R. (1996). Embriologia comparada. Jaboticabal: FUNEP.

Lönning, S., Kjorsvik, E. \& Davenport, J. (1984). The hardening process of the chorion of the cod, Gadus morhua L. and lampsucker, Cyclopterous lumpus L. J. Fish Biol. 24, 505-22.

Matkovic, M.V., Cussac, V.E. \& Cukier, M. (1985). Desarrollo embrionário de Rhamdia sapo (Valenciennes, 1840) 
Eigenmann Y Eigenmann, 1888 (Pisces, Pimelodidae). I. Segmentación, morfogénesis y organogenesis temprana. Rev. Bras. Biol. 45, 39-50.

Morrison, C.M., Miyake, T. \& Wright, J. Jr (2001). Histological study of the development of the embryo and early of Oreochromis niloticus (Pisces, Cichlidae). J. Morphol. 247, 172-95.

Ninhaus-Silveira, A., Foresti, F. \& Azevedo, A. (2006). Structural and ultrastructural analysis of embryonic development of Prochilodus lineatus (Valenciennes, 1836) (Characiformes, Prochilodontidae). Zygote 14, 217-29.

Nakatani, K., Agostinho, A.A., Baumgartner, G., Bialetzki, A., Sanches, P.V. \& Cavicchioli, M. (2001). Ovos e larvas de peixes de água doce, desenvolvimento e manual de identificação. Maringá: UEM, Nupélia.

Ohta, T. (1985). Electron microscopy observations on sperm entry and pronuclear formation in naked eggs of the rose bitterling in polyspermic fertilization. J. Exp. Zool. 234, 27381.

Ribeiro, C.R., Leme dos Santos, H.S. \& Bolzan, A.A. (1995). Estudo comparativo da embriogênese de peixes ósseos (Pacu, Piaractus mesopotamicus, Tambaqui, Colossoma macropomum e híbrido Tambacu). Rev. Bras. Biol. 55, 65-78.

Rizzo, E. \& Bazzoli, N. (1993). Oogenesis, oocyte surface and micropylar apparatus of Prochilodus affinis Reinhardt, 1874 (Pisces Characiformes). Eur. Arch. Biol. 104, 1-6.
Sanches, P.V., Nakatani, K. \& Bialetzki, A. (1999). Morphological description of the developmental stages of Parauchenipterus galeatus (Linnaeus, 1766) (Silurifores, Auchenipteridae) on the floodplain of the upper Paraná River. Rev. Bras. Biol. 59, 429-38.

Sargent, R.C., Taylor, P.D. \& Gross, M.R. (1987). Parental care and evolution of egg size in fishes. Am. Nat. 121, 32-46.

Shardo, J.D. (1995). Comparative embryology of teleostean fishes. I. Development and staging of the American Shad, Alosa sapidissima (Wilson, 1811). J. Morphol. 225, 125-67.

Suzuki, H.I. (1992). Variações na morfologia ovariana e no desenvolvimento do folículo de peixes teleósteos da bacia do rio Paraná no trecho entre a foz do rio Paranapanema e a do rio Iguaçu. Masters Degree, Universidade Federal do Paraná, Curitiba.

Tolosa, E.M.C., Behmer, O.A. \& Freitas-Neto, A.G. (2003). Manual de técnicas para histologia normal e patológica. BarueriSP: Manole.

Vazzoler, A.E.A.M. (1996). Biologia da reprodução de peixes teleósteos: teoria e prática. NUPÉLIA. Maringá: EDUEM.

Wourms, J.P. \& Evans, D. (1974). The embryonic development of the black prickleback, Xiphister atropurpureus, a Pacific Coast blennioid fish. Can. J. Zool. 52, 879-87.

Woynarovich, E. \& Hovárt, L. (1983). A propagação artificial de peixes de águas tropicais. Brasília, DF: FAO/CODEVASFCNPq, (Manual de Extensão, 5). 